\title{
Productive sinus of the proximal humerus
}

\section{B Garg, E Krishnakiran, R Malhotra, S Bhan}

Answers on $p 412$.

$\mathrm{A}$ 60 year old man was admitted to our department suffering for the past eight years with productive sinuses of the right humerus (fig 1). He underwent several drainages and postoperatively he was treated with albendazole. Unfortunately the results were poor with total osteolysis of humeral head, with persistent, productive sinuses.

\section{QUESTIONS}

(1) What is the diagnosis and differential diagnosis?
(2) What are the other sites of involvement?

(3) What is the treatment?

Postgrad Med J 2005;81:411

doi: $10.1136 /$ pgmi.2004.025452

\section{Authors' affiliations}

B Garg, E Krishnakiran, R Malhotra, S Bhan Department of Orthopaedics, All India Institute of Medical Sciences, New Delhi, India

Correspondence to: Dr B Garg, Department of Orthopaedics, All India Institute of Medical Sciences, New Delhi, India; drbhavukgarg@ rediffmail.com

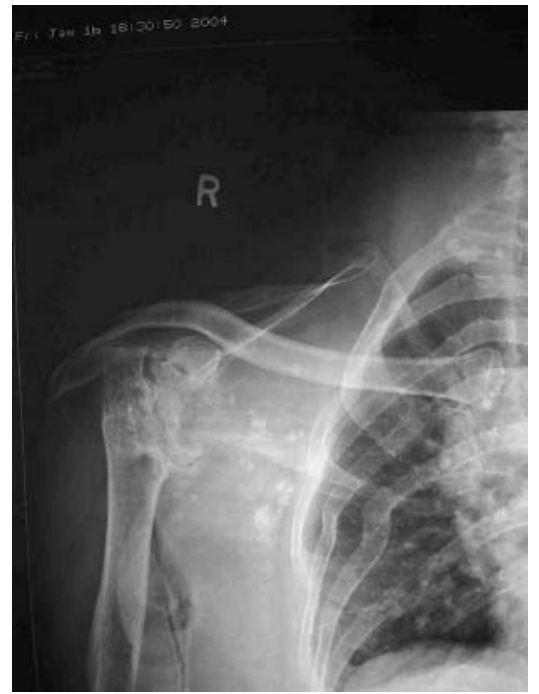

Figure 1 Plain AP radiograph of the right shoulder of the patient showing osteolysis of humeral head, soft tissue swelling, and soft tissue calcification.

Submitted 12 June 2004 Accepted 23 July 2004

\section{WEB TRAWL}

This month we feature two web sites concerned with resuscitation.

http://www.resus.org.uk This is the official web site of the Resuscitation Council (UK); a body that facilitates education on resuscitation both for those working in healthcare, and also the general population. The home page simply provides a list of links to the other pages on the site, which cover topics including guidelines, courses, publications, and ongoing research. The guidelines page is of particular importance. The page itself is simply another list of links, but these links are to documents including the current guidelines on resuscitation, standards for practice and training, and advice for members of the public undertaking resuscitation. The courses page provides links to a comprehensive list of courses, covering all aspects of adult and paediatric resuscitation. Dates of current courses and contact details are given for those wishing to register, although it is not possible to register directly through the web site. A list of publications produced by the council is provided, along with an order form that may be downloaded. Once again however, it is not possible to order any of these publications on line. Overall, this is a simple, easy to use web site, which contains a great deal of essential information on current practice in life support in the UK. The last update to the web site is dated April 2005, so users may be reassured that the information provided is the most up to the minute available.

http://www.erc.edu This is the web site of the European Resuscitation Council, which, although some of the information parallels that available on the UK Council web site, does have some additional features that users from all countries may find of value. A detailed home page allows the visitor to navigate to numerous links covering events, courses, and publications. The site seems to be aimed almost exclusively at the health professional, and offers the user the facility to register (basic registration is free), and then to take part in an online forum, which has a number of different "topics" or "threads" that the user can then contribute to. Surprisingly, the web site seems to be provided entirely in English, and there does not seem to be the facility to view the site in other languages, even though the registration form asks the user to select one or more spoken languages. Among the resources provided, perhaps the most valuable is the educational material. A number of items are available for downloading (often at no charge), including algorithms, manuals, and Powerpoint presentations for use in training. Once again, this web site seemed to be up to date, with details of courses and meetings to be held within the next few weeks. The online forum also seems popular, with recent contributions to the various discussions from contributors all over Europe. Much of the information and resources contained on this site is very general, and would be of use to healthcare providers in many countries, perhaps even outside of Europe. 